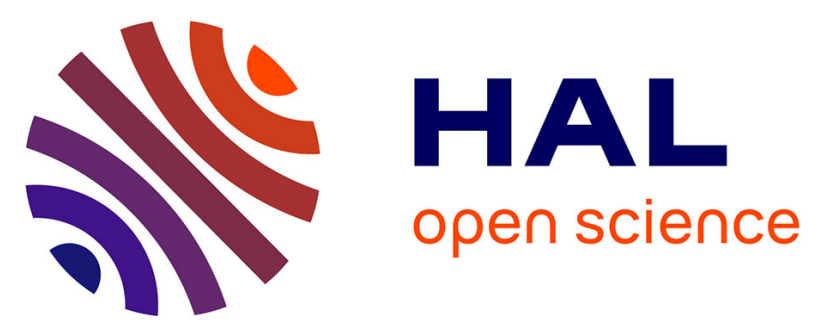

\title{
Reactivity and Structural Diversity in the Reaction of Guanidine 1,5,7-Triazabicyclo[4.4.0]dec-5-ene with CO 2 , CS 2 , and Other Heterocumulenes
}

Niklas von Wolff, Claude Villiers, Pierre Thuéry, Guillaume Lefèvre, Michel Ephritikhine, Thibault Cantat

\section{To cite this version:}

Niklas von Wolff, Claude Villiers, Pierre Thuéry, Guillaume Lefèvre, Michel Ephritikhine, et al.. Reactivity and Structural Diversity in the Reaction of Guanidine 1,5,7-Triazabicyclo[4.4.0]dec-5-ene with CO 2 , CS 2 , and Other Heterocumulenes. European Journal of Organic Chemistry, 2017, 2017, pp.676-686. 10.1002/ejoc.201601267 . cea-01447886

\section{HAL Id: cea-01447886 https://hal-cea.archives-ouvertes.fr/cea-01447886}

Submitted on 27 Jan 2017

HAL is a multi-disciplinary open access archive for the deposit and dissemination of scientific research documents, whether they are published or not. The documents may come from teaching and research institutions in France or abroad, or from public or private research centers.
L'archive ouverte pluridisciplinaire HAL, est destinée au dépôt et à la diffusion de documents scientifiques de niveau recherche, publiés ou non, émanant des établissements d'enseignement et de recherche français ou étrangers, des laboratoires publics ou privés. 


\title{
Reactivity and Structural Diversity in the Reaction of the TBD Guanidine with $\mathrm{CO}_{2}, \mathrm{CS}_{2}$ and Other Heterocumulenes
}

\author{
Niklas von Wolff, ${ }^{[a]}$ Claude Villiers, ${ }^{[a]}$ Pierre Thuéry, ${ }^{[a]}$ Guillaume Lefèvre, ${ }^{[a]}$ \\ Michel Ephritikhine ${ }^{*[a]}$ and Thibault Cantat ${ }^{*[a]}$
}

\begin{abstract}
The guanidine 1,5,7-triazabicyclo[4.4.0]dec-5-ene (TBD) reacted with the heterocumulenes $\mathrm{CO}_{2}, \mathrm{CS}_{2}, \mathrm{iPr}_{2} \mathrm{NCN} \mathrm{Pr}_{2}$, ptolyINCO and ptolyINCS to give three types of products: $\mathrm{TBD}-\mathrm{CO}_{2}(\mathbf{1})$ and TBD-ptolyINCS (5), resulting from addition of the cumulene to TBD, $\operatorname{TBD}(-\mathrm{H})(\{\operatorname{PrNH}\}-\mathrm{C}=\mathrm{N}\{\operatorname{Pr}\}) \quad(3)$ and $\operatorname{TBD}(-\mathrm{H})($ ptolylNHCO) (4), resulting from addition of the $\mathrm{N}-\mathrm{H}$ bond of $\mathrm{TBD}$ to the $\mathrm{C}=\mathrm{N}$ bond of the cumulene, and dithiocarbamate salt $[\operatorname{TBDH}]\left[\mathrm{TBD}(-\mathrm{H}) \mathrm{CS}_{2}\right](2)$ after transfer of a proton to a second molecule of TBD. Competition reactions indicated that the order of decreasing stability of the compounds is: $\mathbf{4}>\mathbf{5}>\mathbf{1}>\mathbf{2}>\mathbf{3}$. DFT calculations showed that the relative stabilities of the products are governed by both the Lewis acidity of the heterocumulene and the Brønsted basicity of the TBD($\mathrm{H})$-cumulene anion, while their distinct structures are determined by the latter, with the most basic site governing the geometry of the final product.
\end{abstract}

\section{Introduction}

The chemical valorization of $\mathrm{CO}_{2}$ as a $\mathrm{C} 1$ building block has witnessed significant progresses for the last few years. ${ }^{[1]}$ In order to efficiently reduce $\mathrm{CO}_{2}$ in economically viable processes, the thermodynamic stability and the kinetic inertness of this molecule have to be overcome. Consequently, an efficient reductive functionalization of $\mathrm{CO}_{2}$ requires catalysts able to synchronize $\mathrm{C}$ $\mathrm{O}$ bond cleavage with $\mathrm{C}-\mathrm{C}$ and $\mathrm{C}-\mathrm{H}$ bond formation, with a low energy demand. The activation of $\mathrm{CO}_{2}$ mediated by metallic centers from $\mathrm{d}$ and $\mathrm{f}$ blocks has been widely explored during the last 40 years. ${ }^{[2]}$ In contrast, the exploration of the scope of organocatalysts able to promote $\mathrm{CO}_{2}$ activation is much more recent. Such transformations can involve nucleophilic partners such as $\mathrm{N}$-heterocyclic carbenes (NHCs), Frustrated Lewis Pairs (FLPs), or guanidines. ${ }^{[3]}$ We focused more specifically our recent efforts on the role played by the $\mathrm{FLP} / \mathrm{CO}_{2}$ adducts involving guanidines as nucleophiles, such as 1,5,7triazabicyclo[4.4.0]dec-5-ene (TBD, Scheme 1a), in organocatalytic reductive transformations of $\mathrm{CO}_{2} \cdot{ }^{[4]}$ We could demonstrate that these adducts were excellent catalysts for the hydroboration of $\mathrm{CO}_{2}$ to the methanol level, using 9borabicyclo[3.3.1]nonane (9-BBN) as a reductant (Scheme 1b). ${ }^{[3 \mathrm{~b}]}$ Importantly, it was shown that the involvement of such adducts in the hydroboration process depends on their thermodynamic stability. ${ }^{[5]}$

a)<smiles>O=C1C(=O)N2CCCN3CCCN2[C@H]13</smiles>

b) $3 \mathrm{R}_{2} \mathrm{BH}+\mathrm{CO}_{2} \stackrel{\text { cat. }}{\longrightarrow} 2 \mathrm{R}_{2} \mathrm{BOBR}_{2}+\mathrm{CH}_{3} \mathrm{OBR}_{2}$
In organic synthesis, heterocumulenes $\mathrm{X}=\mathrm{C}=\mathrm{Y}(\mathrm{X}, \mathrm{Y}=\mathrm{NR}, \mathrm{O}, \mathrm{S})$ are narrowly related to the $\mathrm{CO}_{2}$ molecule and exhibit a close reactivity since they similarly feature a $s p$ hybridized carbon atom doubly bound to two more electronegative elements ( $\mathrm{S}, \mathrm{N}$ and/or O). ${ }^{[6]}$ Analogously to $\mathrm{CO}_{2}$, heterocumulenes can undergo insertion reactions in organometallic complexes, ${ }^{[7]}$ leading in some cases to the cleavage of the $\mathrm{C}=\mathrm{Y}$ bond. ${ }^{[8]}$ They can also undergo addition reactions onto main-group cations in $\mathrm{Zn}$ - and $\mathrm{Li}$ based bio-inspired systems, ${ }^{[9]}$ and they are also widely employed in transannulation and cycloaddition reactions. ${ }^{[10]}$

In order to map out the differences in reactivity and structures between $\mathrm{CO}_{2}$ and the heterocumulenes, we decided to extend the structural analysis of the guanidine- $\mathrm{CO}_{2}$ adducts to representative heterocumulene analogues. Herein, we report the synthesis, structural characterization (by NMR and single-crystal X-ray diffraction) and reactivity of several TBD-heterocumulene adducts, involving carbon disulfide, isocyanate (ptolyINCO), isothiocyanate (ptolyINCS) and diimide $\left(\mathrm{Pr}_{2} \mathrm{NCN} / \mathrm{Pr}_{2}\right)$ organic derivatives as Lewis acids and TBD as a Lewis base (Scheme 2). Trends in structures and relative stability are established, from experimental and theoretical (DFT) results, based on the different Lewis acidity of the heterocumulenes.
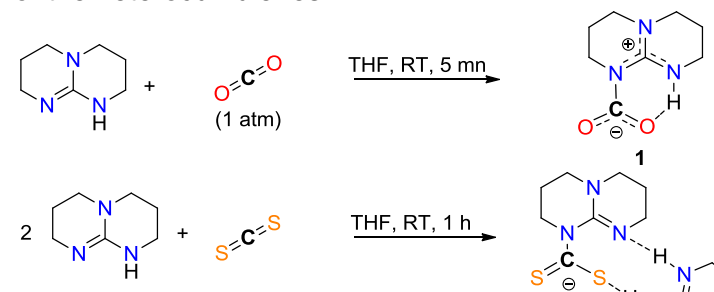

$(98 \%)$

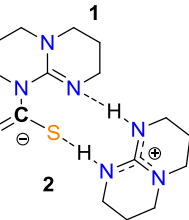

$(96 \%)$
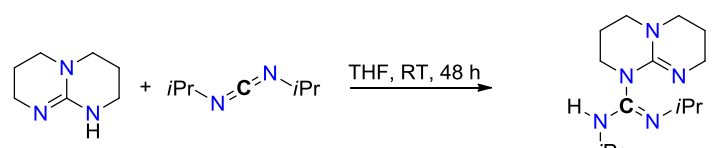

iPr

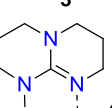

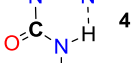

$(>99 \%)$
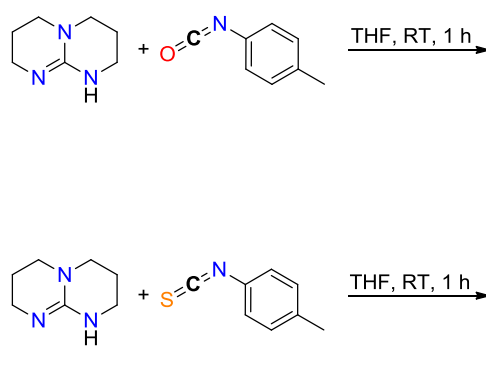

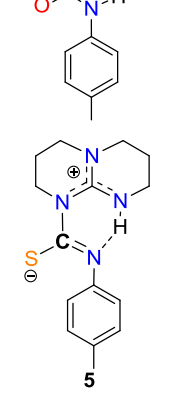

$(>99 \%)$

Scheme 1. a) TBD-CO 2 adduct 1 and b) Catalytic hydroboration of $\mathrm{CO}_{2}$ to methoxyborane. 


\section{Results and Discussion}

Synthesis and Crystal Structures of the Compounds. The $\mathrm{TBD}-\mathrm{CO}_{2}$ adduct 1 readily precipitated as an off-white powder upon diffusion of $\mathrm{CO}_{2}$ into a THF solution of TBD under strictly anhydrous conditions (Scheme 2). X-ray diffraction analysis of the colorless crystals obtained by heating a THF suspension of TBD in a $\mathrm{CO}_{2}$ atmosphere revealed the zwitterionic structure of the molecule, composed of the guanidinium-type delocalized cationic system and the carboxylate-type anionic fragment, as described in our preliminary communication. ${ }^{[4]}$ The structure of adduct 1 differs from the product of addition of $\mathrm{CO}_{2}$ to simple amines, which form carbamate salts in the presence of $\mathrm{CO}_{2}$. Crystallization of TBD- $\mathrm{CO}_{2}$ was found afterwards to afford a polymorph of the same molecule 1 (Figure 1) which crystallizes in the monoclinic space group $P 2_{1} / C$, instead of the orthorhombic $P 2_{1} 2_{1} 2_{1}$ in the former case. These two forms, which are in fact obtained both together in THF and other solvents (benzene, acetonitrile, pyridine and cyclohexane), exhibit quite identical geometrical parameters (Table 1). In particular, the mean $\mathrm{C} 1-\mathrm{N}$ distances of the planar C1N1N2N3 units are 1.34(2) and 1.346(16) $\AA$, the average C8-O distances are 1.241(12) and 1.243(14) $\AA$, the N1C8 distances are 1.475(3) and 1.480(3) $\AA$, and the O1-C8-O2 angles are 128.7(2) and $128.59(19)^{\circ}$ in the monoclinic and orthorhombic crystals, respectively. In both cases, an intramolecular hydrogen bond between the hydrogen atom bound

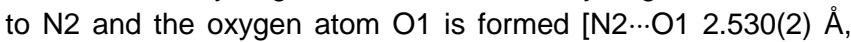

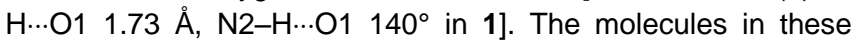
polymorphic variants are nearly superimposable, the main differences being found in their packing. In both cases, the molecules are arranged in columns parallel to the a axis, but the packing of columns is different in the two forms (Fig. S1). Both arrangements are equivalent in terms of packing efficiency, with Kitaigorodski packing index values of 0.745 in the orthorhombic form and 0.750 in the monoclinic form (estimation with PLATON ${ }^{[11]}$.

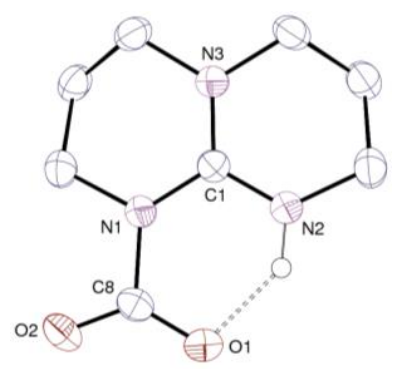

Figure 1. View of TBD- $\mathrm{CO}_{2}$ (1). Displacement ellipsoids are drawn at the $50 \%$ probability level. Carbon-bound hydrogen atoms are omitted. The hydrogen bond is shown as a dashed line.

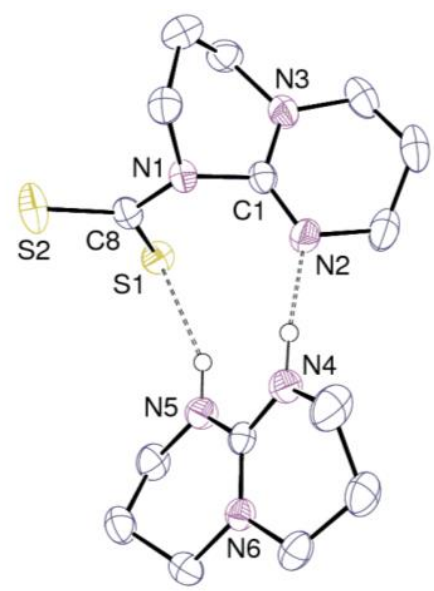

Figure 2. View of [TBDH][TBD $\left.(-\mathrm{H}) \mathrm{CS}_{2}\right]$ (2). Displacement ellipsoids are drawn at the $50 \%$ probability level. Carbon-bound hydrogen atoms are omitted. The hydrogen bonds are shown as dashed lines. Only one position of the disordered atom is represented.

Treatment of TBD with 1 mol equiv of $\mathrm{CS}_{2}$ in THF did not lead to the formation of the adduct TBD-CS ${ }_{2}$ (2') but gave after evaporation of the solvent light yellow crystals of the guanidinium dithiocarbamate $[\mathrm{TBDH}]\left[\mathrm{TBD}(-\mathrm{H}) \mathrm{CS}_{2}\right]$ (2) (where $\operatorname{TBD}(-\mathrm{H})$ represents the deprotonated TBD). 2 is the expected product of the reaction of a secondary amine and $\mathrm{CS}_{2}$, as $\left[\mathrm{R}_{2} \mathrm{NH}_{2}\right]\left[\mathrm{R}_{2} \mathrm{NCO}_{2}\right]$ is the expected product of the reaction of $\mathrm{R}_{2} \mathrm{NH}$ and $\mathrm{CO}_{2}$. The crystal structure of $\mathbf{2}$ is presented in Figure 2 while selected bond lengths and angles are listed inTable 1 . The geometry of the $\mathrm{R}_{2} \mathrm{NCS}_{2}$ fragment is unexceptional for a dithiocarbamate group, ${ }^{[12]}$ with the average C8-S distance of $1.700(7) \AA$, the N1-C8 distance of 1.383(3) $\AA$ and the S1-C8-S2 angle of 123.57(9) ${ }^{\circ}$. The long C1-N1 and short C1-N2 distances of 1.4357(19) and $1.281(2) \AA$ indicate that the canonical form represented in Scheme 2 brings a significant contribution to the true structure of the $\operatorname{TBD}(-\mathrm{H}) \mathrm{CS}_{2}$ anion in 2. The guanidinium cation $[\mathrm{TBDH}]^{+}$, which is identical to that found in $[\mathrm{TBDH}] \mathrm{X}\left(\mathrm{X}=\mathrm{Cl}, \mathrm{BPh}_{4}\right)$ or $[\mathrm{TBDH}]_{2}\left[\mathrm{PtCl}_{4}\right]_{,},{ }^{[13]}$ is linked to the anion by two hydrogen bonds

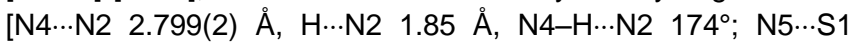

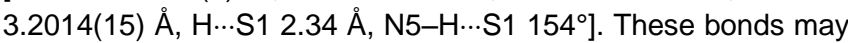
in part induce the torsion of the $\mathrm{CS}_{2}$ group which is almost perpendicular to the mean plane of the $\mathrm{CN}_{3}$ unit of the $\operatorname{TBD}(-\mathrm{H})$ fragment, with a dihedral angle of $80.33(9)^{\circ}$

Table 1. Selected Bond Lengths $(\AA)$ and Angles $\left(^{\circ}\right)$ in the Compounds TBD- $\mathrm{CO}_{2},[\operatorname{TBDH}]\left[\operatorname{TBD}(-\mathrm{H}) \mathrm{CS}_{2}\right]$ and $\operatorname{TBD}(-\mathrm{H})(\{\operatorname{PrNH}\}-\mathrm{C}=\mathrm{N}\{i \mathrm{Pr}\}$

TBD-CO $2(X=O)$ orthorhombic $\quad \operatorname{TBD}_{2} \mathrm{CO}_{2}(\mathrm{X}=\mathrm{O})$ monoclinic $\quad[\operatorname{TBDH}][\operatorname{TBD}(-\mathrm{H}) \mathrm{CS} 2](\mathrm{X}=\mathrm{S}) \quad \mathrm{TBD}(-\mathrm{H})(\{\operatorname{PrNH}\}-\mathrm{C}=\mathrm{N}\{i \operatorname{Pr}\})(\mathrm{X}=\mathrm{N})$




\begin{tabular}{|c|c|c|c|c|}
\hline $\mathrm{C} 1-\mathrm{N} 1$ & $1.369(3)$ & $1.372(3)$ & $1.4357(19)$ & $1.3856(16)$ \\
\hline $\mathrm{C} 1-\mathrm{N} 2$ & $1.332(2)$ & $1.325(3)$ & $1.281(2)$ & $1.2878(16)$ \\
\hline C1-N3 & $1.338(3)$ & $1.333(3)$ & $1.348(2)$ & $1.3749(16)$ \\
\hline $\mathrm{N} 1-\mathrm{C} 8$ & $1.480(3)$ & $1.475(3)$ & $1.383(2)$ & $1.4482(16)$ \\
\hline $\begin{array}{l}\text { X1-C8 } \\
\text { or N4-C8 }\end{array}$ & $1.257(3)$ & $1.252(3)$ & $1.7066(17)$ & $1.3530(16)$ \\
\hline $\begin{array}{l}\text { X2-C8 } \\
\text { or N5-C8 }\end{array}$ & $1.229(2)$ & $1.229(3)$ & $1.6926(16)$ & $1.2756(16)$ \\
\hline $\mathrm{N} 1-\mathrm{C} 1-\mathrm{N} 2$ & $118.42(19)$ & $118.15(18)$ & $119.26(15)$ & $117.59(11)$ \\
\hline $\mathrm{N} 1-\mathrm{C} 1-\mathrm{N} 3$ & $121.09(17)$ & $121.21(18)$ & $112.16(13)$ & $116.57(11)$ \\
\hline $\mathrm{N} 2-\mathrm{C} 1-\mathrm{N} 3$ & $120.49(19)$ & $120.63(18)$ & $128.27(15)$ & $125.81(11)$ \\
\hline $\begin{array}{l}\mathrm{N} 1-\mathrm{C} 8-\mathrm{X} 1 \\
\text { or N1-C8-N4 }\end{array}$ & $117.18(18)$ & $117.41(18)$ & $117.31(11)$ & $111.35(10)$ \\
\hline $\begin{array}{l}\mathrm{N} 1-\mathrm{C} 8-\mathrm{X} 2 \\
\text { or N1-C8-N5 }\end{array}$ & $114.22(17)$ & $113.93(19)$ & $119.11(12)$ & $125.93(11)$ \\
\hline $\begin{array}{l}\mathrm{X} 1-\mathrm{C} 8-\mathrm{X} 2 \\
\text { or N4-C8-N5 }\end{array}$ & $128.59(19)$ & $128.7(2)$ & $123.57(9)$ & $122.47(11)$ \\
\hline
\end{tabular}



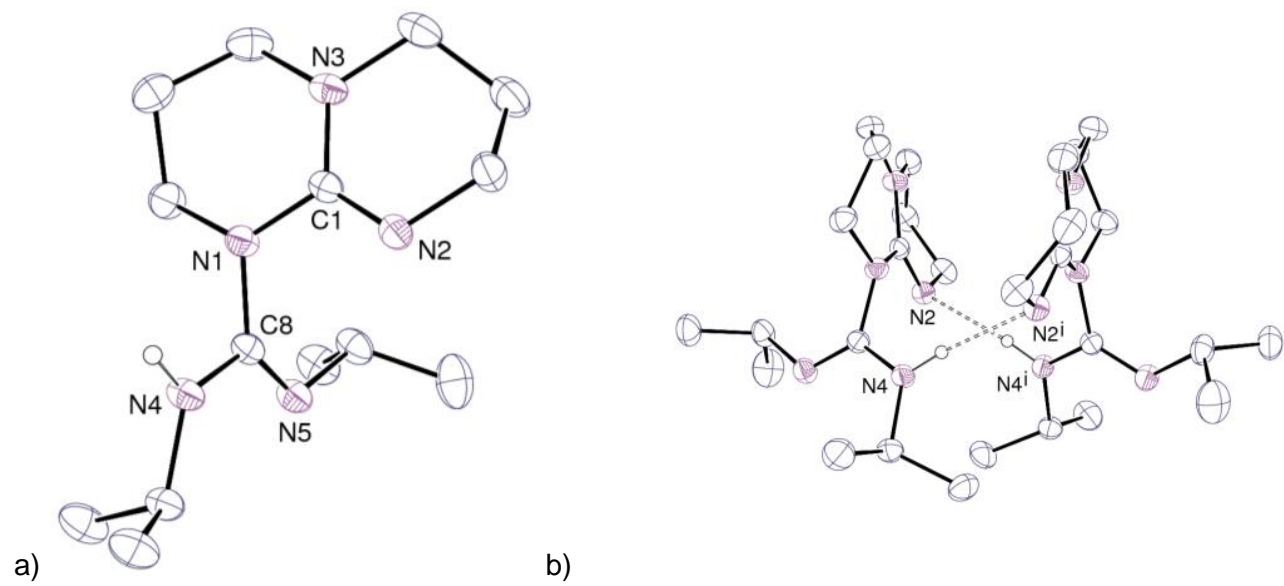

b)

Figure 3. (a) View of $\operatorname{TBD}(-\mathrm{H})(\{\mathrm{PrNH}\}-\mathrm{C}=\mathrm{N}\{\mathrm{Pr}\})(3)$. (b) Dimerization through hydrogen bonding in 3 . Displacement ellipsoids are drawn at the $30 \%$ probability level. Carbon-bound hydrogen atoms are omitted. The hydrogen bonds are shown as dashed lines. Symmetry code: $i=-x, y, 1 / 2-z$.

The biguanide $\operatorname{TBD}(-\mathrm{H})(\{\mathrm{PrNH}\}-\mathrm{C}=\mathrm{N}\{\operatorname{Pr}\})(3)$ was previously synthesized in THF or DMF through the nucleophilic addition of TBD to the $N, N$ diisopropylcarbodiimide and was isolated as a viscous oil. ${ }^{[14]}$ We found that colorless crystals of this compound were formed in quantitative yield after 2 days from a 1:1 mixture of the reactants in the absence of solvent (Scheme 2). The crystal structure (Figure 3a) confirms that the molecule can be seen as resulting from the insertion of the $\mathrm{N}-\mathrm{H}$ bond of TBD into one of the $\mathrm{C}=\mathrm{N}$ bond of $\mathrm{PrN}=\mathrm{C}=\mathrm{NiPr}$. The localized bonding scheme along the biguanide skeleton N2N3C1N1C8N4N5 clearly reflects the major contribution of the canonical form shown in Scheme 2 in particular with the short C1-N2 and C8-N5 distances of $1.2878(16)$ and $1.2756(16) \AA .{ }^{[15]}$ The two mean planes defined respectively by the N1C8N4N5 and N1C1N2N3 atoms (rms deviations 0.017 and $0.006 \AA$, respectively) form a dihedral angle of $80.90(5)^{\circ}$, an arrangement which is likely governed by the presence of two intermolecular hydrogen bonds building a

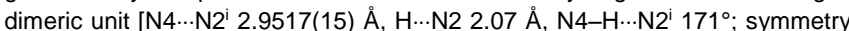
code: $\mathrm{i}=-x, y, 1 / 2-z]$ (Figure $3 b$ ). The ${ }^{1} \mathrm{H}$ NMR spectra of the crystals in THF$d_{8}$ at $23{ }^{\circ} \mathrm{C}$ revealed that the molecule is in equilibrium with its free components $\mathrm{TBD}$ and $\mathrm{PrN}=\mathrm{C}=\mathrm{N} / \mathrm{Pr}$ with relative proportions of 82:18.

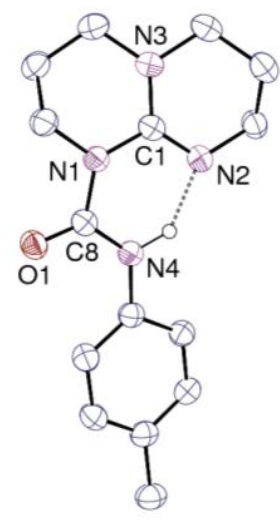

Figure 4. View of $\operatorname{TBD}(-\mathrm{H})($ ptolyINHCO) (4). Displacement ellipsoids are drawn at the $50 \%$ probability level. Carbon-bound hydrogen atoms are omitted. The hydrogen bond is shown as a dashed line.

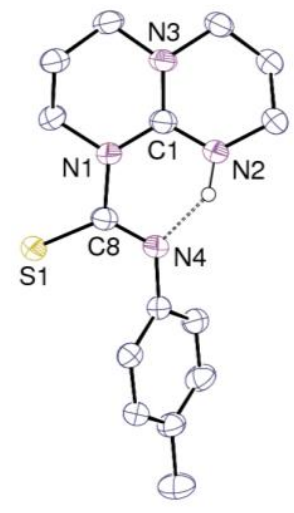

Figure 5. View of TBD-ptolyINCS (5). Displacement ellipsoids are drawn at the $50 \%$ probability level. Carbon-bound hydrogen atoms are omitted. The hydrogen bond is shown as a dashed line.

It was recently reported that reaction of TBD with benzylisocyanate gave the urea $\operatorname{TBD}(-\mathrm{H})\left(\mathrm{PhCH}_{2} \mathrm{NHCO}\right)$ as a pale yellow oil while the zwitterionic adduct MeTBD-RNCO, featuring a guanidinium and a carbamide ions, was proposed as an intermediate in the synthesis of the urethane linkage of RNHCOOR' from RNCO and R'OH using MeTBD as a catalyst. ${ }^{[16]}$ We found that reactions of TBD with 1 mol equiv. of the alkyl isocyanates and alkyl isothiocyanates $\mathrm{RN}=\mathrm{C}=\mathrm{O}$ and $\mathrm{RN}=\mathrm{C}=\mathrm{S}$ ( $\mathrm{R}$ $=\mathrm{Et}, \mathrm{Cy}$ ) also afforded viscous oils. The ${ }^{1} \mathrm{H}$ NMR spectra do not permit to determine the structure of the products, $\operatorname{TBD}(-$ $\mathrm{H})(\mathrm{RNHCX})$ or TBD-RNCX (X = O or S). Nevertheless, off-white powders precipitated from THF solutions of TBD and ptolyINCO or ptolyINCS in the 1:1 molar ratio and crystallization from benzene afforded colorless crystals. X-ray diffraction analysis revealed the quite distinct structures of the compounds: $\operatorname{TBD}(-$ $\mathrm{H})(\mathrm{RNHCO})(4)$ and TBD-RNCS ( $\mathrm{R}=$ ptolyl) (5) (Figure 4 and Figure 5) which markedly differ in their geometrical parameters (Table 1). The former compound results from the insertion of the $\mathrm{N}-\mathrm{H}$ bond of TBD into one of the $\mathrm{C}=\mathrm{N}$ double bond of the 
isocyanate, as it was proposed for $\operatorname{TBD}(-\mathrm{H})\left(\mathrm{PhCH}_{2} \mathrm{NHCO}\right)$. It is best represented by the canonical form shown in Scheme 2, with the long $\mathrm{C} 1-\mathrm{N} 1$ and short $\mathrm{C} 1-\mathrm{N} 2$ distances of $1.4137(17)$ and 1.2929(18) $\AA$. Replacement of ptolylNCO with $p \mathrm{CF}_{3} \mathrm{C}_{6} \mathrm{H}_{5} \mathrm{NCO}$ in its reaction with TBD gave crystals of a benzene solvate of the analogous urea $\operatorname{TBD}(-\mathrm{H})\left(p \mathrm{CF}_{3} \mathrm{C}_{6} \mathrm{H}_{5} \mathrm{NHCO}\right)$ (6) which exhibits quite identical metrical parameters (Table 2), showing that the presence of the electron-withdrawing $\mathrm{CF}_{3}$ group has no influence on the structure of the product (Fig. S2). The adduct TBDptolyINCS adopts, like TBD- $\mathrm{CO}_{2}$, a zwitterionic structure represented in Scheme 2. The average $\mathrm{C} 1-\mathrm{N}$ distance of the guanidinium fragment is equal to 1.35(3) $\AA$ while the geometry of the ptolyINCS unit is similar to that found in isothiocyanate molecules coordinated to transition metals. ${ }^{[8 b, 17]}$ For example, the
C8-S1 and C8-N4 distances of 1.7004(17) and 1.301(2) $\AA$ and the N4-C8-S1 angle of $127.43(13)^{\circ}$ can be compared to the corresponding values of 1.736(5) $\AA$, 1.256(6) $\AA$ and $135.0(4)^{\circ}$ in the molybdenum complex trans, mer-[Mo(tolylNC) $)_{2}\left(\square^{2}\right.$ TolNCS $\left.)\left(\eta^{3}-\mathrm{P}_{4}=\mathrm{S}\right)\right]\left[\mathrm{P}_{4}=\right.$ meso-o- $\left.\mathrm{C}_{6} \mathrm{H}_{4}\left(\mathrm{PPhCH}_{2} \mathrm{CH}_{2} \mathrm{PPh}_{2}\right)_{2}\right]{ }^{\left[{ }^{[8 b}\right]}$ These linkages are longer than those measured in linear free isothiocyanates. ${ }^{[18]}$ In both molecules, the N2 and N4 atoms of the TBD and ptolyINCX $(X=O, S)$ fragments are linked by a hydrogen bond, $\mathrm{N} 2$ and $\mathrm{N} 4$ being the acceptor atoms in $\mathbf{4}$ and $\mathbf{5}$,

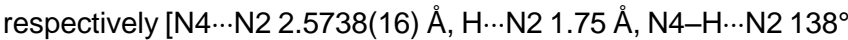

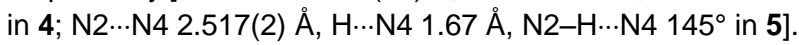

Table 2. Selected Bond Lengths $(\AA)$ and Angles $\left(^{\circ}\right)$ in the Compounds TBD $(-H)($ ptolylNHCO), TBD $(-H)(p C F 3 C 6 H 5 N H C O)$ and TBD-ptolylNCS

$\operatorname{TBD}(-\mathrm{H})\left(\right.$ ptolyINHCO) $(\mathrm{X}=\mathrm{O}) \quad \mathrm{TBD}(-\mathrm{H})\left(\mathrm{pCF}_{3} \mathrm{C}_{6} \mathrm{H}_{5} \mathrm{NHCO}\right)(\mathrm{X}=\mathrm{O}) \quad$ TBD-ptolylNCS $(\mathrm{X}=\mathrm{S})$

\begin{tabular}{llll} 
C1-N1 & $1.4137(17)$ & $1.4174(18)$ & $1.383(2)$ \\
C1-N2 & $1.2929(18)$ & $1.2907(19)$ & $1.323(2)$ \\
C1-N3 & $1.3666(17)$ & $1.3628(19)$ & $1.336(2)$ \\
N1-C8 & $1.4163(17)$ & $1.4116(19)$ & $1.454(2)$ \\
N4-C8 & $1.3499(17)$ & $1.3536(19)$ & $1.301(2)$ \\
X1-C8 & $1.2273(16)$ & $1.2260(17)$ & $1.7004(17)$ \\
N1-C1-N2 & $119.68(12)$ & & $119.65(15)$ \\
N1-C1-N3 & $115.51(12)$ & $118.90(12)$ & $120.44(15)$ \\
N2-C1-N3 & $124.77(13)$ & $116.13(12)$ & $119.91(16)$ \\
N1-C8-N4 & $115.07(11)$ & $124.95(13)$ & $115.24(15)$ \\
N1-C8-X1 & $119.77(12)$ & $115.31(12)$ & $117.28(12)$ \\
X1-C8-N4 & $125.15(12)$ & $119.58(13)$ & $127.43(13)$ \\
\hline
\end{tabular}

Competition Reactions. In order to determine the relative stability of products $\mathbf{1 - 5}$, compound $\mathbf{1}$ was treated with the other cumulenes in competition reactions (Scheme 3). The carbodiimide derivative $\operatorname{TBD}(-\mathrm{H})(\{\operatorname{PrNH}\}-\mathrm{C}=\mathrm{N}\{\operatorname{Pr}\}) \quad(3)$ is obviously the least stable compound in this series since it is the only one involved in an equilibrium with its constituents TBD and iPrN=C=NiPr in THF solution. The TBD- $\mathrm{CO}_{2}$ adduct 1 was inert in the presence of $1 \mathrm{~mol}$ equiv of $\mathrm{CS}_{2}$ or $\mathrm{PrN}=\mathrm{C}=\mathrm{NiPr}$ and accordingly, $\mathbf{1}$ was formed in quantitative yield from reactions of $[\mathrm{TBDH}]\left[\mathrm{TBD}(-\mathrm{H}) \mathrm{CS}_{2}\right](2)$ or $\mathrm{TBD}(-\mathrm{H})(\{\operatorname{PrNH}\}-\mathrm{C}=\mathrm{N}\{\operatorname{Pr}\})(3)$ with $\mathrm{CO}_{2}$. The same equilibrating mixture of 1 and TBD-ptolyINCS (5) in the molar ratio of $1: 2$ was obtained by treatment of $\mathbf{1}$ and $\mathbf{5}$ with 1 mol equiv of ptolyINCS and $\mathrm{CO}_{2}$, respectively. In contrast, the equimolar mixture of $\mathbf{1}$ and ptolyINCO was totally converted into $\operatorname{TBD}(-\mathrm{H})(\mathrm{RNHCO})(4)$ which was inert under $\mathrm{CO}_{2}$ atmosphere. These reactions indicate that the order of stability is the following:

$\mathrm{TBD}(-\mathrm{H})($ ptolyINHCO) (4) > TBD-ptolyINCS (5) > TBD-CO 2 (1) > $[\mathrm{TBDH}]\left[\mathrm{TBD}(-\mathrm{H}) \mathrm{CS}_{2}\right](\mathbf{2})>\mathrm{TBD}(-\mathrm{H})(\{\mathrm{PrNH}\}-\mathrm{C}=\mathrm{N}\{\mathrm{Pr}\})(\mathbf{3})$.

The order of reactivity of heterocumulenes toward nucleophilic substrates is thought to depend on different parameters (Lewis acidity, $\mathrm{Nu}-\mathrm{C}$ bond strength, HSAB principle, etc.) and can vary depending on the system under investigation. ${ }^{[6,19]}$ We were therefore interested to rationalize the observed trend of reactivity 
and to understand the underlying principles governing both the stability and the geometry of the final TBD-cumulene product using DFT calculations.

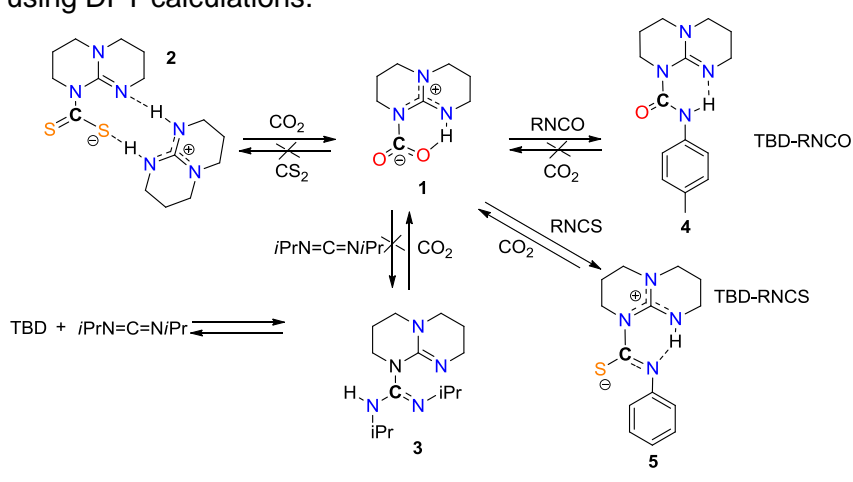

Scheme 3. Competition reactions $(R=p t o l y l)$.

$$
\text { insertion }
$$
carbodiimide

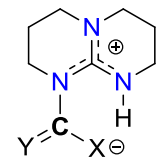

addition

$\mathrm{XCY}=\mathrm{CO}_{2}$, $p$-ToINCS

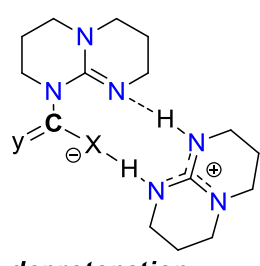

deprotonation

For $\mathrm{XCY}=\mathrm{CS}_{2}$
Scheme 4. Different observed geometries for the reaction products of TBD with the indicated cumulenes.
Theoretical Analysis. From an experimental point of view, it was shown that TBD reacts with different heterocumulenes to yield three types of products (insertion, addition and deprotonation, Scheme 4) and their relative stability was established by competition experiments. Both toluene isocyanate (ptolylNCO) and diisopropyl carbodiimide were found to insert into the $\mathrm{N}-\mathrm{H}$ bond of TBD, while $\mathrm{CO}_{2}$ and toluene isothiocyanate undergo addition to TBD to form a formal zwitterionic adduct. Within the PBE0/D3/6-31+G* level of theory and using PCM (Polarizable Continuum Model) as implemented in the Gaussian code to account for solvation by THF, the three observed geometry types were reproduced accurately. Addition products TBD- $\mathrm{CO}_{2}(\mathbf{1})$ and TBD-ptolyINCS (5) are characterized by a pronounced cationic charge of +0.72 on the guanidine system (Table 3 , entries 2 and 3 ), which is stabilized by delocalization of the surrounding nitrogen lone pairs. As a consequence, the three $\mathrm{N}-\mathrm{C}$ bond lengths are similar (1.325-1.373 $\AA$ ) and possess a Wiberg bond index of 1.22-1.32. On the other hand, insertion products TBD($\mathrm{H})(\{\mathrm{PrNH}\}-\mathrm{C}=\mathrm{N}\{\mathrm{Pr}\})(3)$ and $\operatorname{TBD}(-\mathrm{H})($ ptolylNHCO) (4) show a somewhat lower charge of +0.65 and +0.67 , respectively, on the central carbon of the guanidine system. The Wiberg $\mathrm{C}-\mathrm{N}$ bond indexes vary from 1.06 to 1.61 and from 1.05 to 1.57 for $\mathbf{3}$ and $\mathbf{4}$, respectively, indicative of a lower degree of delocalization in the guanidine backbone, in agreement with the canonical forms depicted in Scheme 2 (Table 3, entries 1 and 5). This trend results in a charge buildup on the nitrogen atom of the $\operatorname{TBD}(-\mathrm{H})$ fragment and in a short $\mathrm{N}-\mathrm{C}$ bond lengths between $\operatorname{TBD}(-\mathrm{H})$ and the heterocumulene (1.416 and $1.448 \AA$ for 3 and 4 , respectively, vs $1.476 \AA$ for 5 ; Table 3). With the lowest charge on the guanidine system and pronounced $\pi$-donation from nitrogen towards the cumulene, the $\mathrm{C}-\mathrm{N}$ bond length between $\operatorname{TBD}(-\mathrm{H})$ and $\mathrm{CS}_{2}$ in $[\mathrm{TBDH}]\left[\mathrm{TBD}(-\mathrm{H}) \mathrm{CS}_{2}\right](\mathbf{2})$ is particularly short $(1.369 \AA)$ and features a Wiberg bond index of 1.16 (vs 1.0 in $\mathbf{4}$ and 0.82 in 1;

\begin{tabular}{|c|c|c|c|c|c|c|c|c|}
\hline Entry & Product & $\mathrm{XCY}$ & $\Delta \mathrm{G}\left(\mathrm{kcal} \cdot \mathrm{mol}^{-1}\right)^{[\mathrm{a}]}$ & $\mathrm{qC}^{[\mathrm{b}]}$ & $\mathrm{qC}(\mathrm{XCY})^{[\mathrm{c}]}$ & Wiberg guanidine $e^{[d]}$ & Wiberg $X C Y^{[e]}$ & $\mathrm{N} 1-\mathrm{C}(\mathrm{X}) \mathrm{Y}$ Length $(\AA)^{[\mathrm{f}]}$ \\
\hline 1 & 4 & ptolyINCO & -13.4 & 0.67 & 0.85 & $1.05 / 1.57$ & 1.0 & $1.415(1.4163(17))$ \\
\hline 2 & 1 & $\mathrm{CO}_{2}$ & -8.3 & 0.72 & 0.94 & $1.23 / 1.31$ & 0.82 & $1.541(1.480(3))$ \\
\hline 3 & 5 & ptolyINCS & -6.2 & 0.72 & 0.26 & $1.22 / 1.32$ & 0.89 & $1.476(1.454(2))$ \\
\hline 4 & 2 & $\mathrm{CS}_{2}$ & -6.1 & 0.63 & -0.06 & $0.92 / 1.76$ & 1.16 & $1.369(1.383(2))$ \\
\hline 5 & 3 & $\mathrm{Pr}_{2} \mathrm{NCNiPr}_{2}$ & -5.7 & 0.65 & 0.65 & $1.06 / 1.61$ & 0.90 & $1.437(1.4482(16))$ \\
\hline
\end{tabular}
Table 3).

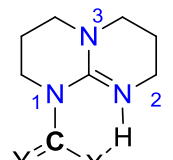

Table 3. Calculated relative stabilities and key parameters for the different TBD-cumulene products.

[a] Calculated relative stability of adducts expressed as the difference of Gibbs free energy with respect to the starting materials. [b] NBO-charge on the central guanidine carbon. [c] NBO-charge on the central cumulene carbon. [d] Wiberg matrix elements between the central guanidine carbon atom and N1/N2 from NBO calculations. [e] Wiberg matrix elements between N1 and the XCY carbon atom from NBO calculations. [f] Calculated gas-phase $\mathrm{N}-\mathrm{C}$ bond length between guanidine $\mathrm{N}$ and the central cumulene carbon atom. Values in parentheses correspond to X-ray diffraction data. 
The relative stability of these adducts was computed and found to be in reasonable agreement with the competition experiments: $\operatorname{TBD}(-\mathrm{H})$ (ptolyINHCO) (4) > TBD-CO2 (1) > TBD-ptolyINCS (5) $>[\mathrm{TBDH}][\mathrm{TBD}(-\mathrm{H}) \mathrm{CS} 2](2)>\mathrm{TBD}(-\mathrm{H})(\{\mathrm{PPrNH}\}-\mathrm{C}=\mathrm{N}\{\mathrm{iPr}\})(3)$. From experiments, the stability of 5 was found to be in between that of 4 and 1 , whereas computationally a slight deviation was observed, i.e. 5 is less stable than 1 (Table 3, entry 3 ). This deviation might be due to solvation effects and the calculation of the toluene isothiocyanate starting material. In fact, a strong influence of the basis set and functional was observed on the C$\mathrm{N}-\mathrm{C}$ bond angle of ptolyINCS and DFT calculations were shown to have problems to correctly account for a correct $\mathrm{C}-\mathrm{N}-\mathrm{C}$ angle. ${ }^{[20]}$ Nonetheless, with the relative free energies in hand, the origins of the differences in stability and structures of compounds 1-5 were investigated.

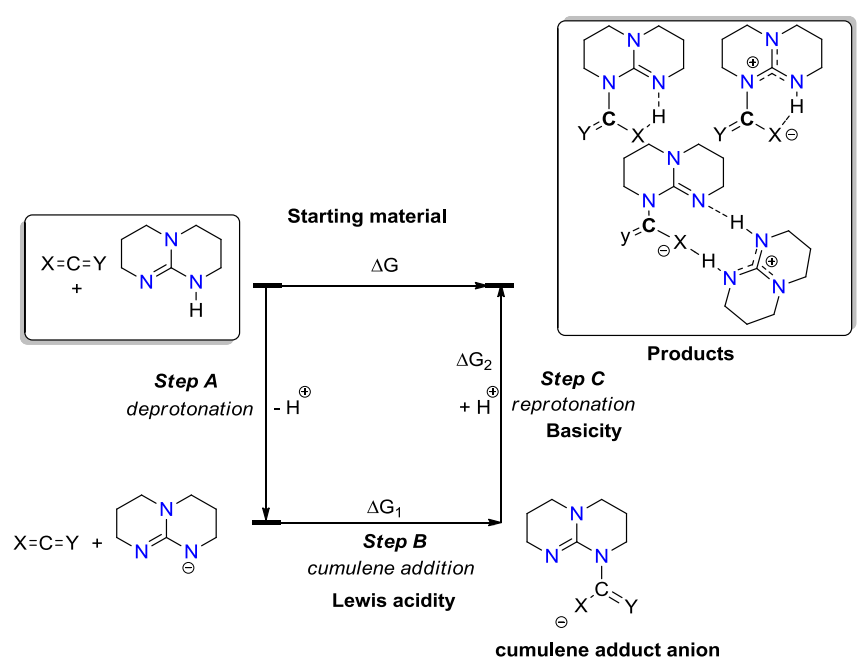

Scheme 5. Thermodynamic cycle for the reaction between TBD and different heterocumulenes. The furan anion was used as a reference base (see experimental section).

\begin{tabular}{|c|c|c|c|c|c|c|}
\hline Entry & $\mathrm{XCY}$ & Product & $\Delta \mathrm{G}_{1}\left(\mathrm{kcal} . \mathrm{mol}^{-1}\right)$ & $\Delta \mathrm{G}_{2}\left(\mathrm{kcal} \cdot \mathrm{mol}^{-1}\right)$ & Deprotonation $\left(\mathrm{kcal}^{\mathrm{mol}}{ }^{-1}\right)$ & $\Delta \mathrm{G}\left(\mathrm{kcal} . \mathrm{mol}^{-1}\right)$ \\
\hline 1 & ptolyINCO & 4 & -21.2 & 22.5 & -14.7 & -13.4 \\
\hline 2 & $\mathrm{CO}_{2}$ & 1 & -20.9 & 27.3 & -14.7 & -8.3 \\
\hline 3 & $\mathrm{CS}_{2}$ & 2 & -28.4 & 36.9 & -14.7 & -6.2 \\
\hline 4 & ptolyINCS & 5 & -23.6 & 32.1 & -14.7 & -6.1 \\
\hline 5 & $\mathrm{Pr}_{2} \mathrm{NCN}_{i} \mathrm{Pr}_{2}$ & 3 & -5.7 & 14.6 & -14.7 & -5.7 \\
\hline
\end{tabular}

Based on a thermodynamic cycle (Scheme 5), it was shown that the overall stability is mainly governed by two factors. The formation of the products can be divided into three hypothetical distinct steps (steps A, B and C, Scheme 5). First, TBD is deprotonated to yield the $\operatorname{TBD}(-\mathrm{H})$ anion. The Gibbs-free energy associated with this first step does not depend on the nature of the cumulene $\left(-14.7 \mathrm{kcal}_{\mathrm{mol}}^{-1}\right.$, Table 4$)$. The so-formed TBD($\mathrm{H})$ anion can then react in step $B$ with the different heterocumulenes $\mathrm{X}=\mathrm{C}=\mathrm{Y}$ to form the $\operatorname{TBD}(-\mathrm{H}) \mathrm{XCY}$ adduct anion. The exergonicity of this reaction $\left(\Delta G_{1}\right)$ depends on the Lewis acidic character of the cumulene and is thus a measure for their relative Lewis acidity. Re-protonation in step $C$ then provides the final product. Interestingly, step $C$ depends on the capability of the $\operatorname{TBD}(-\mathrm{H}) \mathrm{XCY}$ anion to stabilize a proton and the most basic site in the anion will govern the geometry and structure of the final product. As step A is identical for all the cumulenes, the overall Gibbs free energy $(\Delta G)$ depends solely on steps $B$ and $C$. Consequently, the Lewis acidity of the cumulenes alone is not a good descriptor of the relative stability of the final products. As shown in Table $4\left(\Delta G_{1}\right), C_{2}$ is the strongest Lewis acid $\left(\Delta G_{1}=-\right.$ $28.4 \mathrm{kcal}^{\mathrm{mol}}{ }^{-1}$, entry 3 ), followed by the thioisocyanate ($23.6 \mathrm{kcal}^{\mathrm{mol}}{ }^{-1}$, entry 4$)$, the isocyanate $\left(-21.2 \mathrm{kcal}^{\mathrm{mol}}{ }^{-1}\right.$, entry 1$)$, $\mathrm{CO}_{2}\left(-20.9 \mathrm{kcal}^{\mathrm{mol}}{ }^{-1}\right.$, entry 2$)$ and finally the carbodiimide ($5.7 \mathrm{kcal}^{\mathrm{mol}}{ }^{-1}$, entry 5$)$. On the other hand, the $\operatorname{TBD}(-\mathrm{H}) \mathrm{XCY}$ anion of the latter is by far the strongest base $\left(\Delta G_{2}=\right.$ $\left.14.6 \mathrm{kcal}^{\mathrm{mol}} \mathrm{m}^{-1}\right)$, followed by the corresponding anion of 4 $\left(22.5 \mathrm{kcal}^{\mathrm{mol}}{ }^{-1}\right)$. In $\mathrm{CO}_{2}$ adduct 1 (27.3 kcal.mol $\left.{ }^{-1}\right)$ and isothiocyanate adduct $5\left(32.1 \mathrm{kcal}^{\mathrm{mol}}{ }^{-1}\right)$ the acidic proton is only weakly stabilized. Finally, the basicity of the $\operatorname{TBD}(-\mathrm{H}) \mathrm{CS}_{2}$ anion is weaker than that of free TBD and $\mathbf{2}$ forms a dithiocarbamate salt $\left(36.9 \mathrm{kcal}^{\mathrm{mol}}{ }^{-1}\right)$. The strongest Lewis acid $\left(\mathrm{CS}_{2}\right)$ therefore does not form the most stable adduct. It is noteworthy that the relative stability of adducts 1-5 is governed by both Lewis acidity of the heterocumulene XCY the Brønsted basicity of the TBD $(-\mathrm{H}) \mathrm{XCY}$ anion (Figure 6). Figure 6 highlights the unique characteristics of the carbodiimide adduct $\mathbf{3}$ : the anion of $\mathbf{3}$ is by far the strongest 
Brønsted base of the series while carbodiimide $\operatorname{PrN}=\mathrm{C}=\mathrm{NiPr}$ is the weakest Lewis acid. Finally, the structural differences between the three types of products (insertion vs addition vs deprotonation) are mainly controlled by the basicity of the TBD($\mathrm{H}) \mathrm{XCY}$ anion. The carbodiimide- and the isocyanate-based anions exhibit the greatest Brønsted basicity and protonation occurs on the nitrogen atom of the heterocumulene to yield the insertion products 3 and $\mathbf{4}$. In anions $\operatorname{TBD}(-\mathrm{H}) \mathrm{CO}_{2}$ and $\operatorname{TBD}(-$ $\mathrm{H})$ (ptolyINCS), the nitrogen atom of the TBD backbone is the protonation site, thereby leading to the formation of addition products $\mathbf{1}$ and $\mathbf{5}$, respectively. These considerations also help understand why the strongest Lewis acid $\left(\mathrm{CS}_{2}\right)$ does not form a stable adduct similar to $\mathrm{CO}_{2}$ adduct 1 . Indeed, the putative TBD$\mathrm{CS}_{2}$ adduct 2' presents a low pKa of 25.0 vs 28.0 for $\mathbf{1}$ and 25.5 for 2 (Scheme 6). As comparison, free TBD has a pKa-value of 31.2, where a difference in pKa of one unit corresponds approximately to a difference in Gibbs free energy of $0.6 \mathrm{kcal} . \mathrm{mol}^{-1}$ at $298 \mathrm{~K}$. Protonation of the $\operatorname{TBD}(-\mathrm{H}) \mathrm{CS}_{2}$ anion therefore occurs on the free TBD to afford the observed dithiocarbamate salt $[\mathrm{TBDH}]\left[\mathrm{TBD}(-\mathrm{H}) \mathrm{CS}_{2}\right](2)$.

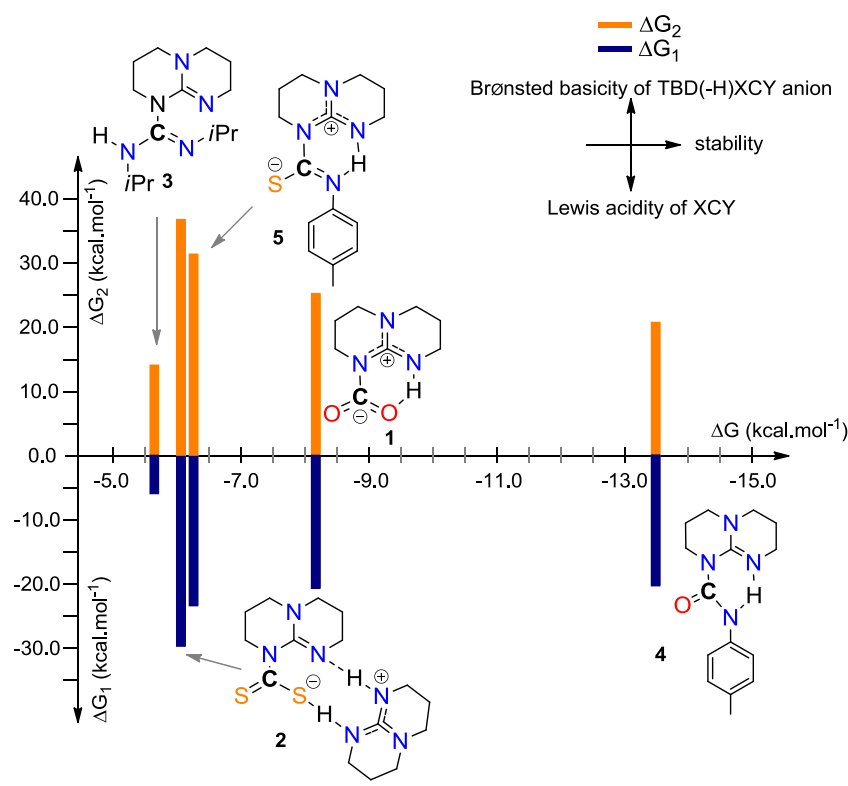

Figure 6. Computed Gibbs free energies associated with the formation of adducts 1-5; Representation of the influence of Lewis acidity and basicity on the overall Gibbs free energy of product formation for the different TBD-XCY species.

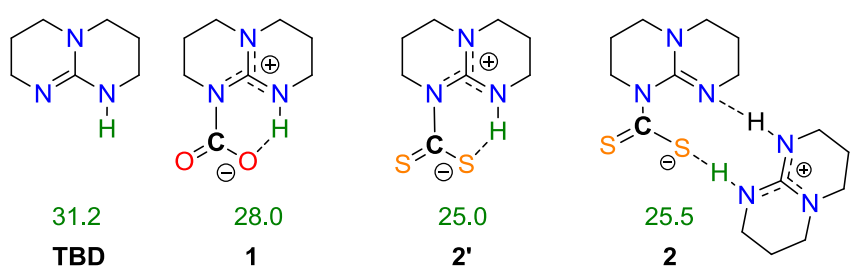

Scheme 6. Calculated pKa values of selected (green) protons in TBD, TBD$\mathrm{CO}_{2}(\mathbf{1})$, a hypothetical TBD-CS 2 adduct (2') and the observed dithiocarbamate salt [TBDH][TBD $\left.(-\mathrm{H}) \mathrm{CS}_{2}\right](2)$

\section{Conclusions}

The guanidine TBD reacted with the heterocumulenes $\mathrm{CO}_{2}, \mathrm{CS}_{2}$, $\mathrm{Pr}_{2} \mathrm{NCN} / \mathrm{Pr}_{2}$, ptolyINCO and ptolyINCS to afford three types of products resulting either from (i) the addition of the cumulene to TBD (providing zwitterionic compounds TBD- $\mathrm{CO}_{2} 1$ and TBDptolyINCS 5), (ii) the formal insertion of the cumulene into the $\mathrm{N}-$ $\mathrm{H}$ bond of TBD (giving TBD $(-\mathrm{H})(\{\mathrm{PrNH}\}-\mathrm{C}=\mathrm{N}\{\operatorname{Pr}\}) 3$ and $\operatorname{TBD}(-$ $\mathrm{H})$ (ptolyINHCO) 4), or (iii) the formation of a guanidium salt by deprotonation of the corresponding adduct by a free TBD molecule ([TBDH][TBD $\left.(-H) \mathrm{CS}_{2}\right]$ 2). Competition reactions indicated that the order of stability of the compounds is: TBD($\mathrm{H})\left(\right.$ ptolyINHCO) (4) > TBD-ptolyINCS (5) > TBD- $\mathrm{CO}_{2}(1)>$ $[\mathrm{TBDH}]\left[\mathrm{TBD}(-\mathrm{H}) \mathrm{CS}_{2}\right]$ (2) > TBD $(-\mathrm{H})(\{\mathrm{PrNH}\}-\mathrm{C}=\mathrm{N}\{\operatorname{PPr}\})$ These results were rationalized by DFT calculations, which showed that the relative stabilities of the products are governed by both the Lewis acidity of the heterocumulene and the Brønsted basicity of the $\operatorname{TBD}(-\mathrm{H})$-cumulene anion. Their distinct structures are determined by the basicity of the $\operatorname{TBD}(-\mathrm{H})$-cumulene anion, in which the most basic site governs the geometry of the final product.

\section{Experimental Section}

General Procedure. All reactions were carried out under argon with the rigorous exclusion of air and water ( $<5$ ppm oxygen or water) using standard Schlenk-vessel and vacuum line techniques or in a glove box. Solvents were thoroughly dried by standard methods and distilled immediately before use. The commercial reagents (Fluka, Aldrich) $N, N$ diisopropylcarbodiimide, isocyanates $\mathrm{RNCO}\left(\mathrm{R}=\mathrm{Et}, \mathrm{Cy}\right.$, ptolyl, $p \mathrm{CF}_{3} \mathrm{C}_{6} \mathrm{H}_{5}$ ) and isothiocyanates RNCS ( $\mathrm{R}=\mathrm{Et}, \mathrm{Cy}$, ptolyl) have been used as received. The ${ }^{1} \mathrm{H}$ and ${ }^{13} \mathrm{C}\left\{{ }^{1} \mathrm{H}\right\}$ NMR spectra were recorded on a Bruker DPX 200 instrument $(200 \mathrm{MHz})$ at $23^{\circ} \mathrm{C}$ and referenced internally using the residual protic solvent resonances relative to tetramethylsilane $(\delta=0.0)$. Elemental analyses were performed by Analytische Laboratorien at Lindlar (Germany) or by Medac Ltd. at Chobham (UK). Discrepancies in the carbon contents were attributed to the labile nature of the adducts.

Synthesis of $\quad 2,3,4,6,7,8$-hexahydro- $1 H$-pyrimido[1,2 a]pyrimidin-9-ium-9-carboxylate (TBD- $\left.\mathrm{CO}_{2}(1)\right)$. The synthesis and characterization of the TBD- $\mathrm{CO}_{2}$ adduct were described in the preliminary communication and are recalled in part here for convenience. A flask containing TBD $(60.5 \mathrm{mg}, 0.43 \mathrm{mmol})$ in THF $(0.5 \mathrm{~mL})$ was freezed in liquid nitrogen, degassed under vacuum and filled with $\mathrm{CO}_{2}$ (1 atm). The white powder of $\mathrm{TBD}-\mathrm{CO}_{2}$ was immediately deposited at $20^{\circ} \mathrm{C}$; the solvent was 
discarded by decantation and the product was dried under vacuum $(78 \mathrm{mg}$ $0.42 \mathrm{mmol}, 98 \%$ ). Anal. Calcd. for $\mathrm{C}_{8} \mathrm{H}_{13} \mathrm{~N}_{3} \mathrm{O}_{2}$ : C, 52.45; $\mathrm{H}, 7.15 ; \mathrm{N}, 22.93$. Found: $\mathrm{C}, 51.93 ; \mathrm{H}, 7.27 ; \mathrm{N}, 22.71 .{ }^{1} \mathrm{H}$ NMR (THF-d8 under $1 \mathrm{~atm} \mathrm{CO}_{2}$ ): $\delta_{\mathrm{H}} 12.0$ (br s, $1 \mathrm{H}, \mathrm{NH}$ ), 3.30 (t, $J=6.0 \mathrm{~Hz}, 4 \mathrm{H}, \mathrm{CH}_{2}$ ), 3.18 (t, $J=6.0 \mathrm{~Hz}$, $4 \mathrm{H}, \mathrm{CH}_{2}$ ), 1.82 (q, $J=6.1 \mathrm{~Hz}, 4 \mathrm{H}, \mathrm{CH}_{2}$ ). ${ }^{1} \mathrm{H}$ NMR (THF-d 8 under argon): $\delta_{\mathrm{H}}$ 8.02 (br s, 1H, NH), 3.17 (t, $J=6.0 \mathrm{~Hz}, 4 \mathrm{H}, \mathrm{CH}_{2}$ ), 3.03 (t, $J=6.0 \mathrm{~Hz}, 4 \mathrm{H}$, $\mathrm{CH}_{2}$ ), $1.76\left(\mathrm{q}, J=6.1 \mathrm{~Hz}, 4 \mathrm{H}, \mathrm{CH}_{2}\right) \cdot{ }^{13} \mathrm{C}\left\{{ }^{1} \mathrm{H}\right\}$ NMR $\left(\mathrm{MeCN}-d_{3}\right): \delta_{\mathrm{C}} 154.4$ $\left(\mathrm{CO}_{2}\right), 154.0\left(\mathrm{CN}_{3}\right), 49.1\left(\mathrm{CH}_{2}\right), 40.9\left(\mathrm{CH}_{2}\right), 21.9\left(\mathrm{CH}_{2}\right)$.

Synthesis of $\quad 2,3,4,6,7,8$-hexahydro- $1 H$-pyrimido[1,2a]pyrimidin-9-ium 2,3,4,6,7,8-hexahydro-1 $H$-pyrimido[1,2a]pyrimidine-1-carbodithioate ([TBDH][TBD(-H)CS $\mathrm{CS}_{2}$ (2)). Carbon disulfide $(60 \mu \mathrm{L}, 1.00 \mathrm{mmol})$ was added dropwise to a solution of TBD (139 $\mathrm{mg}, 1.00 \mathrm{mmol})$ in THF (5 mL). After $1 \mathrm{~h}$ at $20^{\circ} \mathrm{C}$, the solvent was slowly evaporated leading to the formation of translucent light yellow crystals (170 mg, 96 \%). Anal. Calcd. for $\mathrm{C}_{15} \mathrm{H}_{26} \mathrm{~N}_{6} \mathrm{~S}_{2}$ : C, 50.81; $\mathrm{H}, 7.39 ; \mathrm{N}, 23.70$. Found: C, 51.73; H, 7.57; N, 22.71. ${ }^{1} \mathrm{H}$ NMR (THF- $\left.d_{8}\right): \delta_{\mathrm{H}} 7.57\left(\mathrm{br}, \mathrm{w}_{1 / 2}=\right.$ $30 \mathrm{~Hz}, 2 \mathrm{H}), 4.25$ (t, $J=5.1 \mathrm{~Hz}, 2 \mathrm{H}), 3.28(\mathrm{t}, J=6.0 \mathrm{~Hz}, 2 \mathrm{H}), 3.19(\mathrm{t}, J=5.2$ $\mathrm{Hz}, 2 \mathrm{H}), 3.12$ (t, $J=5.2 \mathrm{~Hz}, 8 \mathrm{H}), 3.00$ (t, $J=5.0 \mathrm{~Hz}, 2 \mathrm{H}), 1.91$ (qt, $J=5.0$ $\mathrm{Hz}, 2 \mathrm{H}$ ), 1.80 (qt, $J=6.2 \mathrm{~Hz}, 6 \mathrm{H}) .{ }^{1} \mathrm{H}$ NMR $\left(\mathrm{MeCN}-d_{3}\right): \delta_{\mathrm{H}}=8.41\left(\mathrm{br}, w^{2} / 2\right.$ $=20 \mathrm{~Hz}, 2 \mathrm{H}, \mathrm{NH}), 4.32\left(\mathrm{t}, J=6.0 \mathrm{~Hz}, 2 \mathrm{H}, \mathrm{CH}_{2}\right), 3.29\left(\mathrm{~m}, 12 \mathrm{H}, \mathrm{CH}_{2}\right), 3.09$ (t, $\left.J=5.2 \mathrm{~Hz}, 2 \mathrm{H}, \mathrm{CH}_{2}\right), 1.96 \mathrm{ppm}\left(\mathrm{m}, 8 \mathrm{H}, \mathrm{CH}_{2}\right) . \mathrm{H} / \mathrm{D}$ exchange was found to occur at room temperature between acetonitrile and the $\mathrm{NH}$ atoms of the compound; the exchange was complete after $2 \mathrm{~h} .{ }^{13} \mathrm{C}\left\{{ }^{1} \mathrm{H}\right\} \mathrm{NMR}$ $\left(\mathrm{MeCN}-d_{3}\right): \delta_{\mathrm{C}} 154.3\left(\mathrm{CN}_{3}\right), 152.3\left(\mathrm{CN}_{3}\right), 50.1,48.8,48.6,47.9,43.2,39.0$, 25.1, 22.4, $22.0\left(\mathrm{CH}_{2}\right)$. The signal of $\mathrm{CS}_{2}$ was not visible.

Synthesis of (Z)- $N, N$-diisopropyl-2,3,4,6,7,8-hexahydro-1Hpyrimido[1,2-a]pyrimidine-1-carboximidamide $\quad(\mathrm{TBD}(-\mathrm{H})(\{\mathrm{iPrNH}\}$ $\mathbf{C}=\mathbf{N}\{\boldsymbol{i P r}\}$ ) (3)). In a slightly modified version of a procedure described elsewhere, ${ }^{[14]} N, N$ '-diisopropylcarbodiimide $(156 \mu \mathrm{L}, 1.0 \mathrm{mmol})$ was added to TBD (139 mg,1.00 mmol). The homogeneous reaction mixture slowly solidified for giving after $2 \mathrm{~d}$ colourless crystals in quantitative yield. Anal. Calcd. for $\mathrm{C}_{14} \mathrm{H}_{27} \mathrm{~N}_{5}$ : C, 63.36; $\mathrm{H}, 10.25 ; \mathrm{N}, 26.39$. Found: $\mathrm{C}, 61.36 ; \mathrm{H}$, 10.17; N, 26.13. ${ }^{1} \mathrm{H}$ NMR (THF- $\left.d 8\right): \delta_{\mathrm{H}} 4.54\left(\mathrm{br}, \mathrm{w}^{1} / 2=10 \mathrm{~Hz}, 1 \mathrm{H}, \mathrm{NH}\right), 3.53$ $\left(\mathrm{m}, 2 \mathrm{H}, \mathrm{CH}_{2}\right), 3.12\left(\mathrm{~m}, 4 \mathrm{H}, \mathrm{CH}_{2}\right), 2.99\left(\mathrm{~m}, 4 \mathrm{H}, \mathrm{CH}\right.$ and $\left.\mathrm{CH}_{2}\right), 1.84(\mathrm{~m}, 2 \mathrm{H}$, $\left.\mathrm{CH}_{2}\right), 1.67\left(\mathrm{~m}, 2 \mathrm{H}, \mathrm{CH}_{2}\right), 0.94\left(\mathrm{~d}, J=5.7 \mathrm{~Hz}, 12 \mathrm{H}, \mathrm{CH}_{3}\right) .{ }^{1} \mathrm{H} \mathrm{NMR}(\mathrm{MeCN}-$ $\left.d_{3}\right): \delta_{\mathrm{H}} 4.62\left(\mathrm{br}, \mathrm{w}_{1 / 2}=10 \mathrm{~Hz}, 1 \mathrm{H}, \mathrm{NH}\right), 3.59\left(\mathrm{~m}, 2 \mathrm{H}, \mathrm{CH}_{2}\right), 3.19(\mathrm{~m}, 4 \mathrm{H}$, $\left.\mathrm{CH}_{2}\right), 3.07\left(\mathrm{~m}, 4 \mathrm{H}, \mathrm{CH}\right.$ and $\left.\mathrm{CH}_{2}\right), 1.92\left(\mathrm{~m}, 2 \mathrm{H}, \mathrm{CH}_{2}\right), 1.73\left(\mathrm{~m}, 2 \mathrm{H}, \mathrm{CH}_{2}\right)$, $1.02\left(\mathrm{~d}, J=5.7 \mathrm{~Hz}, 12 \mathrm{H}, \mathrm{CH}_{3}\right.$ ). The compound was found to slowly dissociate in THF into TBD and $\mathbb{P r N}=\mathrm{C}=\mathrm{NiPr}$ and the equilibrium was reached after $2 \mathrm{~h}$ at $20^{\circ} \mathrm{C}$, with relative proportions of 75:15:15.

Reactions of TBD with isocyanates and isothiocyanates RNCX ( $\mathbf{X}=\mathbf{O}, \mathbf{S}$; R = Et, Cy). (a) EtNCO $(80 \mu \mathrm{L}, 1.00 \mathrm{mmol})$ was added dropwise to a solution of TBD (139 mg, $1.00 \mathrm{mmol})$ in THF $(5 \mathrm{~mL})$. After stirring for $1 \mathrm{~h}$ at $20^{\circ} \mathrm{C}$, the solvent was evaporated off for giving a viscous oil. ${ }^{1} \mathrm{H}$ NMR (THF- $\left.d_{8}\right): \delta_{\mathrm{H}}=11.03\left(\mathrm{br}, w_{1 / 2}=30 \mathrm{~Hz}, 1 \mathrm{H}, \mathrm{NH}\right), 3.66\left(\mathrm{~m}, 2 \mathrm{H}, \mathrm{CH}_{2}\right)$, $3.23\left(\mathrm{t}, J=5.5 \mathrm{~Hz}, 2 \mathrm{H}, \mathrm{CH}_{2}\right), 3.03\left(\mathrm{~m}, 6 \mathrm{H}, \mathrm{CH}_{2}\right), 1.71\left(\mathrm{~m}, 4 \mathrm{H}, \mathrm{CH}_{2}\right), 0.97$ ppm (t, $\left.J=5.7 \mathrm{~Hz}, 3 \mathrm{H}, \mathrm{CH}_{3}\right)$.

(b) EtNCS $(80 \mu \mathrm{L}, 0.92 \mathrm{mmol})$ was added dropwise to a solution of TBD (128 mg, $0.92 \mathrm{mmol})$ in THF $(4 \mathrm{~mL})$. After stirring for $1 \mathrm{~h}$ at $20{ }^{\circ} \mathrm{C}$, the solvent was evaporated off for giving a viscous oil. ${ }^{1} \mathrm{H}$ NMR $\left(\mathrm{THF}-d_{8}\right): \delta_{\mathrm{H}}=$ 13.75(br, $\left.w_{1 / 2}=50 \mathrm{~Hz}, 1 \mathrm{H}, \mathrm{NH}\right), 4.34\left(\mathrm{~m}, 2 \mathrm{H}, \mathrm{CH}, \mathrm{CH}_{2}\right), 3.45$ (q, J=6.2 Hz, $2 \mathrm{H}, \mathrm{CH}_{2}$ ), $3.29\left(\mathrm{t}, J=5.5 \mathrm{~Hz}, 2 \mathrm{H}, \mathrm{CH}_{2}\right), 3.15\left(\mathrm{t}, J=5.5 \mathrm{~Hz}, 2 \mathrm{H}, \mathrm{CH}_{2}\right), 3.07$ (t, $\left.J=5.5 \mathrm{~Hz}, 2 \mathrm{H}, \mathrm{CH}_{2}\right), 1.85\left(\mathrm{~m}, J=5.6 \mathrm{~Hz}, 2 \mathrm{H}, \mathrm{CH}_{2}\right), 1.73\left(\mathrm{~m}, 2 \mathrm{H}, \mathrm{CH}_{2}\right)$, $1.10\left(\mathrm{t}, J=6.2 \mathrm{~Hz}, 3 \mathrm{H}, \mathrm{CH}_{3}\right)$.

(c) CyNCO $(120 \mu \mathrm{L}, 0.94 \mathrm{mmol})$ was added dropwise to a solution of TBD (130 mg, $0.94 \mathrm{mmol})$ in THF $(6 \mathrm{~mL})$. After stirring for $1 \mathrm{~h}$ at $20^{\circ} \mathrm{C}$, the solvent was evaporated off for giving a viscous oil. ${ }^{1} \mathrm{H} N M R\left(T H F-d_{8}\right): \delta_{H}=$ $11.21\left(\mathrm{br}, w_{/ 2}=20 \mathrm{~Hz}, 1 \mathrm{H}, \mathrm{NH}\right), 3.63\left(\mathrm{~m}, 2 \mathrm{H}, \mathrm{CH}_{2}\right), 3.22(\mathrm{t}, J=5.5 \mathrm{~Hz}, 2 \mathrm{H}$,
$\mathrm{CH}_{2}$ ), $3.15\left(\mathrm{t}, J=5.5 \mathrm{~Hz}, 2 \mathrm{H}, \mathrm{CH}_{2}\right), 3.03\left(\mathrm{t}, J=5.5 \mathrm{~Hz}, 2 \mathrm{H}, \mathrm{CH}_{2}\right), 1.74(\mathrm{~m}$, $\left.4 \mathrm{H}, \mathrm{CH}_{2}\right), 1.60-1.10\left(\mathrm{~m}, 11 \mathrm{H}, \mathrm{CH}_{2}\right)$.

(d) CyNCS $(130 \mu \mathrm{L}, 0.92 \mathrm{mmol})$ was added dropwise to a solution of TBD (128 mg,0.92 mmol) in THF (6 mL). After stirring for $1 \mathrm{~h}$ at $20{ }^{\circ} \mathrm{C}$, the solvent was evaporated off for giving a viscous oil. ${ }^{1} \mathrm{H}$ NMR (pyridine- $d_{5}$ ): $\delta_{\mathrm{H}}=14.4\left(\mathrm{br}, w_{1 / 2}=50 \mathrm{~Hz}, 1 \mathrm{H}, \mathrm{NH}\right), 4.5(\mathrm{~m}, 1 \mathrm{H}, \mathrm{CH}), 4.35\left(\mathrm{~m}, 2 \mathrm{H}, \mathrm{CH}_{2}\right)$, 3.20 (t, $\left.J=7.0 \mathrm{~Hz}, 2 \mathrm{H}, \mathrm{CH}_{2}\right), 2.76\left(\mathrm{t}, J=7.0 \mathrm{~Hz}, 2 \mathrm{H}, \mathrm{CH}_{2}\right), 2.62(\mathrm{t}, J=$ $\left.7.0 \mathrm{~Hz}, 2 \mathrm{H}, \mathrm{CH}_{2}\right), 1.89\left(\mathrm{~m}, 2 \mathrm{H}, \mathrm{CH}_{2}\right), 1.5-1.0\left(\mathrm{~m}, 12 \mathrm{H}, \mathrm{CH}_{2}\right)$.

Synthesis of $\mathrm{N}$-(ptolyl)-2,3,4,6,7,8-hexahydro-1H-pyrimido[1,2a]pyrimidine-1-carboxamide (TBD(-H)(ptolyINHCO) (4)). ptolyINCO $(120 \mu \mathrm{L}, 0.95 \mathrm{mmol})$ was added dropwise to a solution of TBD (132 mg, $0.95 \mathrm{mmol})$ in THF (6 mL). After stirring for $1 \mathrm{~h}$ at $20^{\circ} \mathrm{C}$, the solution was evaporated to dryness for giving an off-white powder of the product in quantitative yield. Colorless crystals were obtained by crystallization from benzene. Anal. Calcd. for $\mathrm{C}_{15} \mathrm{H}_{20} \mathrm{~N}_{4} \mathrm{O}$ : C, 66.15; $\mathrm{H}, 7.40 ; \mathrm{N}, 20.57$. Found: $\mathrm{C}, 65.79 ; \mathrm{H}, 7.34 ; \mathrm{N}, 20.07 .{ }^{1} \mathrm{H}$ NMR (benzene- $\left.d_{6}\right): \delta_{\mathrm{H}}=14.6\left(\mathrm{br}, w_{1 / 2}=40\right.$ $\mathrm{Hz}, 1 \mathrm{H}, \mathrm{NH}), 7.92$ (d, J=4.0 Hz, 2H, CH), $7.04(\mathrm{~d}, J=4.0 \mathrm{~Hz}, 2 \mathrm{H}, \mathrm{CH}$ ), 3.75-3.70 (m, 2H, CH 2$), 3.26\left(\mathrm{t}, J=6.0, \mathrm{~Hz}, 2 \mathrm{H}, \mathrm{CH}_{2}\right), 2.47(\mathrm{t}, J=6.0 \mathrm{~Hz}$, $\left.4 \mathrm{H}, \mathrm{CH}_{2}\right), 2.27\left(\mathrm{t}, J=6.0 \mathrm{~Hz}, 2 \mathrm{H}, \mathrm{CH}_{2}\right), 2.11\left(\mathrm{~s}, 3 \mathrm{H}, \mathrm{CH}_{3}\right), 1.40-1.19(\mathrm{~m}$, $\left.4 \mathrm{H}, \mathrm{CH}_{2}\right) .{ }^{13} \mathrm{C}\left\{{ }^{1} \mathrm{H}\right\}$ NMR (benzene- $\left.d_{6}\right): \delta_{\mathrm{C}} 154.9\left(\mathrm{CN}_{3}\right), 151.6(\mathrm{CO}), 139.8$ $(\mathrm{CH}), 132.3(\mathrm{CH}), 130.5(\mathrm{CH}), 120.7(\mathrm{CH}), 50.9\left(\mathrm{CH}_{2}\right), 50.2\left(\mathrm{CH}_{2}\right), 44.4$ $\left(\mathrm{CH}_{2}\right), 41.2\left(\mathrm{CH}_{2}\right), 24.5\left(\mathrm{CH}_{2}\right), 23.8\left(\mathrm{CH}_{2}\right), 21.7\left(\mathrm{CH}_{3}\right)$.

Synthesis of $\mathrm{N}$-(4-(trifluoromethyl)phenyl)-2,3,4,6,7,8-hexahydro-1 $\mathrm{H}$ pyrimido[1,2-a]pyrimidine-1-carboxamide (TBD(-H) $\left(p \mathrm{CF}_{3} \mathrm{C}_{6} \mathrm{H}_{5} \mathrm{NHCO}\right)$ (6)). 4-(trifluoromethyl)phenyl isocyanate $(140 \mu \mathrm{L}, 1.00 \mathrm{mmol})$ was added dropwise to a solution of TBD (139 mg,1.00 mmol) in THF (6 mL). After stirring for $1 \mathrm{~h}$ at $20^{\circ} \mathrm{C}$, the solution was evaporated to dryness for giving an off-white powder of the product in quantitative yield. Colorless crystals of $\mathrm{TBD}(-\mathrm{H})\left(p \mathrm{CF}_{3} \mathrm{C}_{6} \mathrm{H}_{5} \mathrm{NHCO}\right) \cdot 0.5 \mathrm{C}_{6} \mathrm{H}_{6}$ were obtained by crystallization from benzene. Anal. Calcd. for $\mathrm{C}_{18} \mathrm{H}_{20} \mathrm{~F}_{3} \mathrm{~N}_{4} \mathrm{O}$ : C, 55.21; $\mathrm{H}, 5.25 ; \mathrm{N}, 17.17$ Found: C, 54.79; $\mathrm{H}, 5.41 ; \mathrm{N}, 16.61 .{ }^{1} \mathrm{H}$ NMR (benzene- $\left.d_{6}\right): \delta_{\mathrm{H}} 14.56(\mathrm{br}$, $\left.W_{1 / 2}=70 \mathrm{~Hz}, 1 \mathrm{H}, \mathrm{NH}\right), 7.84(\mathrm{~d}, J=4.0 \mathrm{~Hz}, 2 \mathrm{H}, \mathrm{CH}), 7.42(\mathrm{~d}, J=4.0 \mathrm{~Hz}, 2 \mathrm{H}$, $\mathrm{CH}$ ), 3.62 (t, $J=6.0 \mathrm{~Hz}, 2 \mathrm{H}, \mathrm{CH}_{2}$ ), 3.19 (t, $\left.J=6.0 \mathrm{~Hz}, 2 \mathrm{H}, \mathrm{CH}_{2}\right), 2.39$ (t, $J$ $\left.=6.0 \mathrm{~Hz}, 2 \mathrm{H}, \mathrm{CH}_{2}\right), 2.19\left(\mathrm{t}, J=6.0 \mathrm{~Hz}, 2 \mathrm{H}, \mathrm{CH}_{2}\right), 1.35-1.27\left(\mathrm{~m}, 2 \mathrm{H}, \mathrm{CH}_{2}\right)$, 1.17-1.08 $\left(\mathrm{m}, 2 \mathrm{H}, \mathrm{CH}_{2}\right) .{ }^{13} \mathrm{C}\left\{{ }^{1} \mathrm{H}\right\} N M R$ (benzene- $\left.d_{6}\right): \delta_{\mathrm{c}}=154.4\left(\mathrm{CN}_{3}\right)$, 150.2(CO), 144.7(CH), $128.9(\mathrm{CH}), 127.1(\mathrm{CH}), 127.0(\mathrm{CH}), 126.9(\mathrm{CH})$ $126.8(\mathrm{CH}), 120.1(\mathrm{CH}), 118.8(\mathrm{CH}), 49.3\left(\mathrm{CH}_{2}\right), 48.8\left(\mathrm{CH}_{2}\right), 43.2\left(\mathrm{CH}_{2}\right)$, $40.4\left(\mathrm{CH}_{2}\right), 22.8\left(\mathrm{CH}_{2}\right), 22.4 \mathrm{ppm}\left(\mathrm{CH}_{2}\right)$

Synthesis of (Z)- $\mathrm{N}$-ptolyl-2,3,4,6,7,8-hexahydro-1H-pyrimido[1,2a]pyrimidin-9-ium-1-carbimidothioate (TBD-ptolyINCS (5)). A solution of ptolyINCS (134 mg, $0.90 \mathrm{mmol})$ in THF $(3 \mathrm{ml})$ was added to a solution of TBD (125 mg, $0.90 \mathrm{mmol})$ in THF $(6 \mathrm{~mL})$. under stiring. After stirring for $1 \mathrm{~h}$ at $20^{\circ} \mathrm{C}$, the solution was evaporated to dryness for giving an off-white powder of the product in quantitative yield. Colorless crystals were obtained by crystallization from benzene. Anal. Calcd. for $\mathrm{C}_{15} \mathrm{H}_{20} \mathrm{~N}_{4} \mathrm{~S}$ : C, 62.47; H, 6.99; N, 19.42; S, 11.12. Found: C, 62.00; H, 6.80; N, 18.48; S 10.83. ${ }^{1} \mathrm{H}$ NMR (THF- $\left.d_{8}\right): \delta_{\mathrm{H}} 13.8\left(\mathrm{br}, w_{1 / 2}=50 \mathrm{~Hz}, 1 \mathrm{H}, \mathrm{NH}\right), 7.35(\mathrm{~d}, J=$ $4.0 \mathrm{~Hz}, 2 \mathrm{H}, \mathrm{CH}), 7.00(\mathrm{~d}, J=4.0 \mathrm{~Hz}, 2 \mathrm{H}, \mathrm{CH}), 4.46-4.41\left(\mathrm{~m}, 2 \mathrm{H}, \mathrm{CH}_{2}\right), 3.39$ (t, $\left.J=6 \mathrm{~Hz}, 2 \mathrm{H}, \mathrm{CH}_{2}\right), 3.27-3.13\left(\mathrm{~m}, 4 \mathrm{H}, \mathrm{CH}_{2}\right), 2.25\left(\mathrm{~s}, 3 \mathrm{H}, \mathrm{CH}_{3}\right), 1.96-1.79$ $\left(\mathrm{m}, 4 \mathrm{H}, \mathrm{CH}_{2}\right) \cdot{ }^{13} \mathrm{C}\left\{{ }^{1} \mathrm{H}\right\}$ NMR $\left(\mathrm{THF}-d_{8}\right): \delta_{\mathrm{C}} 153.7\left(\mathrm{CN}_{3}\right), 141.8(\mathrm{CS}), 134.8$ $(\mathrm{CH}), 131.9(\mathrm{CH}), 130.0(\mathrm{CH}), 125.5(\mathrm{CH}), 50.4\left(\mathrm{CH}_{2}\right), 50.0\left(\mathrm{CH}_{2}\right), 46.7$, $\left(\mathrm{CH}_{2}\right) 43.5\left(\mathrm{CH}_{2}\right), 24.3\left(\mathrm{CH}_{2}\right), 23.2\left(\mathrm{CH}_{2}\right), 21.9\left(\mathrm{CH}_{3}\right)$.

Competition Reactions. (a) An NMR tube was charged with 1 (10.2 mg, $0.055 \mathrm{mmol})$ and $\mathrm{CS}_{2}(3.3 \mu \mathrm{L}, 0.055 \mathrm{mmol})$ or $\mathrm{iPrN}=\mathrm{C}=\mathrm{NiPr}(8.6 \mu \mathrm{L}, 1.0$ $\mathrm{mmol})$ in THF- $d_{8}(0.5 \mathrm{~mL})$. No reaction was observed after $12 \mathrm{~h}$ at $20^{\circ} \mathrm{C}$.

(b) An NMR tube was charged with 2 (13.0 mg, $0.073 \mathrm{mmol})$ or 3 (14.0 mg, $0.052 \mathrm{mmol})$ in THF- $d_{8}(0.5 \mathrm{~mL})$ and filled with $\mathrm{CO}_{2}$ (1 atm., ca 
1 equiv.). After $2 \mathrm{~h}$ at $20^{\circ} \mathrm{C}$, the ${ }^{1} \mathrm{H}$ NMR spectra showed the complete conversion of $\mathbf{2}$ or $\mathbf{3}$ into $\mathbf{1 .}$

(c) An NMR tube was charged with $5(11.5 \mathrm{mg}, 0.040 \mathrm{mmol})$ in THF$d_{8}(0.5 \mathrm{~mL})$ and filled with $\mathrm{CO}_{2}\left(1 \mathrm{~atm}\right.$., ca 1 equiv.). After $4 \mathrm{~h}$ at $20^{\circ} \mathrm{C}$, the ${ }^{1} \mathrm{H}$ NMR spectrum showed the presence of $\mathbf{1}$ and $\mathbf{5}$ in the molar ratio of 1:2. The same mixture was obtained from $1(10.2 \mathrm{mg}, 0.055 \mathrm{mmol})$ and ptolyINCS (3.7 mg, $0.055 \mathrm{mmol})$ in THF-d $(0.5 \mathrm{~mL})$.

(d) An NMR tube was charged with $1(11.0 \mathrm{mg}, 0.059 \mathrm{mmol})$ and ptolyINCO $(7.5 \mathrm{~mL}, 0.059 \mathrm{mmol})$ in THF- $d_{8}(0.5 \mathrm{~mL})$. After $2 \mathrm{~h}$ at $20^{\circ} \mathrm{C}$, the ${ }^{1} \mathrm{H}$ NMR spectra showed the complete conversion of $\mathbf{1}$ into 4 . No reaction $p K a(T H F)=35+\frac{\Delta \mathrm{G}}{2.303 * \mathrm{R} * \mathrm{~T}} ; \Delta \mathrm{G}$ in $\mathrm{kcal} \cdot \mathrm{mol}^{-1}$ and $\mathrm{T}$ in $\mathrm{K} \cdot{ }^{[23]}$

\section{Acknowledgements}

For financial support of this work, we acknowledge CEA, CNRS, CINES (project c2016086494), the CHARMMMAT Laboratory of Excellence and the European Research Council (ERC Starting Grant Agreement n.336467). T.C. thanks the Foundation Louis D. - Institut de France for its support.

\section{ASSOCIATED CONTENT}

\section{Supporting Information}

Crystallography details, Figures S1 and S2 and optimized geometries and thermochemistry of the computed structures. Accession Codes: CCDC 958202 and 1503371-1503375 contains the supplementary crystallographic data for this paper. These data can be obtained free of charge via www.ccdc.cam.ac.uk/data_request/cif, or by emailing data_request@ccdc.cam.ac.uk, or by contacting The Cambridge Crystallographic Data Centre, 12, Union Road, Cambridge CB2 1EZ, UK; fax: +44 1223336033.

\section{AUTHOR INFORMATION}

Corresponding Authors

*E-mail: michel.ephritikhine@cea.fr; thibault.cantat@cea.fr

The authors declare no competing financial interest.

Keywords: $\mathrm{CO}_{2} \cdot$ Lewis acidity $•$ Cumulene $\cdot$ DFT calculations • TBD

[1] a) Q. Liu, L. Wu, R. Jackstell, M. Beller, Nat Commun 2015, 6; b) A. Tlili, E. Blondiaux, X. Frogneux, T. Cantat, Green Chem. 2015, 17, 157-168; c) A. Goeppert, M. Czaun, J.-P. Jones, G. K. Surya Prakash, G. A. Olah, Chem. Soc. Rev. 2014, 43, 7995-8048.

[2] a) M. Aresta, C. F. Nobile, V. G. Albano, E. Forni, M. Manassero, J. Chem. Soc., Chem. Commun. 1975, 636-637; b) W. Leitner, Coord. Chem. Rev. 1996, 153, 257-284; c) D. Walther, Nach. Chem. Tech. Lab. 1992, 40, 1214-1227; d) D. Walther, M. Ruben, S. Rau, Coord. Chem. Rev. 1999, was observed when an NMR tube containing $4(10.1 \mathrm{mg}, 0.037 \mathrm{mmol})$ in THF- $d_{8}(0.5 \mathrm{~mL})$ was filled with $\mathrm{CO}_{2}$ (1 atm., ca 1 equiv.).

Computational Details. The PBE0 functional was used together with basis set $6-31+G(d)$ for all atoms and Grimme's GD3 correction. ${ }^{[21]}$ All structures were optimized in the gas phase without geometrical constraints, and all stationary points were characterized as minima by frequency calculations. ${ }^{[22]}$ Solvent effects (THF) were taken into account using single point PCM calculations and adding the solvation correction to the gas phase Gibbs free energy terms. The pKa-values were calculated with respect to the furan anion as reference base (experimental value of 35 ) according to the formula:

182, 67-100; e) F. J. Fernandez-Alvarez, A. M. Aitani, L. A. Oro, Catal. Sci. Tech. 2014, 4, 611-624; f) L. Vaska, J. Mol. Catal. 1988, 47, 381 388.

[3] a) M. K. Kiesewetter, M. D. Scholten, N. Kirn, R. L. Weber, J. L. Hedrick, R. M. Waymouth, J. Org. Chem. 2009, 74, 9490-9496; b) C. Das Neves Gomes, E. Blondiaux, P. Thuéry, T. Cantat, Chem. Eur. J. 2014, 20 , 7098-7106; c) S. N. Riduan, Y. Zhang, J. Y. Ying, Angew. Chem. Int. Ed. 2009, 48, 3322-3325; d) F. Bertini, V. Lyaskovskyy, B. J. J. Timmer, F. J. J. de Kanter, M. Lutz, A. W. Ehlers, J. C. Slootweg, K. Lammertsma, J. Am. Chem. Soc. 2012, 134, 201-204; e) I. Peuser, R. C. Neu, X. Zhao, M. Ulrich, B. Schirmer, J. A. Tannert, G. Kehr, R. Fröhlich, S. Grimme G. Erker, D. W. Stephan, Chem. Eur. J. 2011, 17, 9640-9650; f) C. M. Mömming, E. Otten, G. Kehr, R. Fröhlich, S. Grimme, D. W. Stephan, G Erker, Angew. Chem. 2009, 121, 6770-6773; g) F.-G. Fontaine, M.-A. Courtemanche, M.-A. Légaré, Chem. Eur. J. 2014, 20, 2990-2996; h) M.A. Courtemanche, M.-A. Légaré, L. Maron, F.-G. Fontaine, J. Am. Chem. Soc. 2013, 135, 9326-9329; i) B. G. G. Lohmeijer, R. C. Pratt, F. Leibfarth, J. W. Logan, D. A. Long, A. P. Dove, F. Nederberg, J. Choi, C. Wade, R. M. Waymouth, J. L. Hedrick, Macromolecules 2006, 39, 8574-8583; j) V B. Saptal, B. M. Bhanage, Chem. Sus. Chem. 2016, 9, 1980-1985; k) W.C. Chen, J.-S. Shen, T. Jurca, C.-J. Peng, Y.-H. Lin, Y.-P. Wang, W.-C Shih, G. P. A. Yap, T.-G. Ong, Angew. Chem. Int. Ed. 2015, 54, 1520715212; I) S. Das, F. D. Bobbink, S. Bulut, M. Soudani, P. J. Dyson, Chem. Commun. 2016, 52, 2497-2500; m) S. Das, F. D. Bobbink, G. Laurenczy, P. J. Dyson, Angew. Chem. Int. Ed. 2014, 53, 12876-12879.

[4] C. Villiers, J. P. Dognon, R. Pollet, P. Thuéry, M. Ephritikhine, Angew. Chem. Int. Ed. 2010, 49, 3465-3468.

[5] N. von Wolff, G. Lefèvre, J. C. Berthet, P. Thuéry, T. Cantat, ACS Catal. 2016, 6, 4526-4535.

[6] T. Yu, R. Cristiano, R. G. Weiss, Chem. Soc. Rev. 2010, 39, 1435-1447

[7] T. A. Hanna, A. M. Baranger, R. G. Bergman, J. Am. Chem. Soc. 1995, 117, 11363-11364.

[8] a) A. W. Holland, R. G. Bergman, Inorg. Chim. Acta 2002, 341, 99-106 b) T. Ohnishi, H. Seino, M. Hidai, Y. Mizobe, J. Organomet. Chem. 2005 690, 1140-1146.

[9] S. Schenk, J. Notni, U. Kohn, K. Wermann, E. Anders, Dalton Trans. 2006, 4191-4206.

[10] a) S. Chuprakov, S. W. Kwok, V. V. Fokin, J. Am. Chem. Soc. 2013, 135 4652-4655; b) Y. Fukata, K. Asano, S. Matsubara, J. Am. Chem. Soc. 2013, 135, 12160-12163.

[11] A. Spek, J. Appl. Crystallogr. 2003, 36, 7-13.

[12] a) A. Wahlberg, Acta Crystallographica Section B 1978, 34, 3392-3395; b) A. Wahlberg, Acta Crystallographica Section B 1978, 34, 3479-3481; c) A. A. Achilleos, L. R. Gahan, T. W. Hambley, P. C. Healy, D. M Weedon, Inorg. Chim. Acta 1989, 157, 209-214; d) V. P. Fedin, M. N. Sokolov, O. A. Geras'ko, A. V. Virovets, N. V. Podberezskaya, V. Y. Fedorov, Inorg. Chim. Acta 1991, 187, 81-90.

[13] U. Wild, P. Roquette, E. Kaifer, J. Mautz, O. Hübner, H. Wadepohl, H.-J. Himmel, Eur. J. Inorg. Chem. 2008, 2008, 1248-1257.

[14] G. Gelbard, F. Vielfaure-Joly, Tetrahedron Lett. 1998, 39, 2743-2746. 
[15] a) S. H. Oakley, D. B. Soria, M. P. Coles, P. B. Hitchcock, Dalton Trans. 2004, 537-546; b) C.-C. Tai, M.-S. Yu, Y.-L. Chen, W.-H. Chuang, T.-H Lin, G. P. A. Yap, T.-G. Ong, Chem. Commun. 2014, 50, 4344-4346.

[16] J. Alsarraf, Y. A. Ammar, F. Robert, E. Cloutet, H. Cramail, Y. Landais, Macromolecules 2012, 45, 2249-2256.

[17] C. Bianchini, D. Masi, C. C. Mealli, A. Meli, Inorg. Chem. 1984, 23, 2838 2844.

[18] a) B. Rudolf, M. Makowska, A. Domagala, A. Rybarczyk-Pirek, J. Zakrzewski, J. Organomet. Chem. 2003, 668, 95-100; b) J. Vicente, J.A. Abad, J. López-Serrano, P. G. Jones, Organometallics 2004, 23, 4711-4722.

[19] a) T. Ibata, M. Himori, K. Fukushima, H. Suga, H. Nakano, in Heterocyclic Communications, Vol. 2, 1996, p. 87; b) C. Beattie, M. North, Chem. Eur. J. 2014, 20, 8182-8188.

[20] a) M. Cinar, M. Karabacak, S. Chand, V. K. Shukla, L. Sinha, O. Prasad, M. P. Singh, A. M. Asiri, J. Mol. Struct. 2015, 1087, 113-120; b) P. Mani, H. Umamaheswari, B. Dominic Joshua, N. Sundaraganesan, Journal of Molecular Structure: THEOCHEM 2008, 863, 44-49; c) I. Danihel, P. Kristian, S. Böhm, J. Kuthan, Collect. Czech. Chem. Commun. 1987, 52, 2115-2124; d) L. Ulicky, J. Soldanova, Chem. Pap. - Chem. Zvesti 1985 , $39,473-480$.

[21] M. N. Glukhovtsev, A. Pross, M. P. McGrath, J. Radom, J. Chem. Phys. 1995, 103, 1878

[22] R. D. Gaussian 09, M. J. Frisch, G. W. Trucks, H. B. Schlegel, G. E. Scuseria, M. A. Robb, J. R. Cheeseman, G. Scalmani, V. Barone, B. Mennucci, G. A. Petersson, H. Nakatsuji, M. Caricato, X. Li, H. P. Hratchian, A. F. Izmaylov, J. Bloino, G. Zheng, J. L. Sonnenberg, M. Hada, M. Ehara, K. Toyota, R. Fukuda, J. Hasegawa, M. Ishida, T. Nakajima, Y. Honda, O. Kitao, H. Nakai, T. Vreven, J. A. Montgomery, Jr., J. E. Peralta, F. Ogliaro, M. Bearpark, J. J. Heyd, E. Brothers, K. N. Kudin, V. N. Staroverov, T. Keith, R. Kobayashi, J. Normand, K. Raghavachari, A. Rendell, J. C. Burant, S. S. Iyengar, J. Tomasi, M. Cossi, N. Rega, J. M. Millam, M. Klene, J. E. Knox, J. B. Cross, V. Bakken, C. Adamo, J. Jaramillo, R. Gomperts, R. E. Stratmann, O. Yazyev, A. J. Austin, R. Cammi, C. Pomelli, J. W. Ochterski, R. L. Martin, K. Morokuma V. G. Zakrzewski, G. A. Voth, P. Salvador, J. J Dannenberg, S. Dapprich, A. D. Daniels, O. Farkas, J. B. Foresman, J. V. Ortiz, J. Cioslowski, and D. J. Fox, Gaussian, Inc., Wallingford CT, 2013.

[23] K. Shen, Y. Fu, J.-N. Li, L. Liu, Q.-X. Guo, Tetrahedron 2007, 63, 15681576. 